\title{
Research on the Factors of the Innovative Talents in Colleges and Universities
}

\author{
Jing Wang \\ Department of Physics and Technology, Kunming University, Kunming 650214, China
}

745752733@qq.com

Keywords: universities; innovative talents; training mode; reform

\begin{abstract}
From the perspective of cultivating innovative talents in colleges and universities, university construction and talent training models are repositioned based on the theory of innovative talents. First of all, construction must be conducted in universities to ensure the sustainable development; then, universities should create reform of the new talent training models to provide a good talents base for knowledge-based organization and university construction and to improving the competitiveness in the social and employment markets for talents, which can lay a good foundation for students' future career choices and the personal career development of their own. To solve these problems, the talent training models of universities must be taken as the basic starting point.
\end{abstract}

\section{Introduction}

At present, there are many bottlenecks on the road of innovative talent training. With the rapid development of the social economy, along with the increasing quality of people, higher education has gradually transitioned from elite to mass stage. While the number of talents is growing, it is more important to make a difference in quality. Innovative talent training has become the goal of many universities. Compared with some developed countries, the process of training innovative talents is mainly constrained by traditional ideological constraints, unsound innovation training systems, and related conditions that have not reached the required level [1]. Nowadays, the two biggest obstacles to the cultivation of innovative talents are traditional ideological restraint and unscientific training methods. In response to these two points, scholars have proposed to establish a scientific approach to the cultivation of innovative talents in China by changing educational concepts, reforming the process and methods of education, strengthening the construction of teaching staff, and creating an innovative environment for educating people. Building through the transformation of educational concepts, the reform of education and teaching processes and methods, the strengthening of the teaching staff and the creation of an innovative educational environment. The scientific approach to the cultivation of innovative talents in China [2]. To cultivate innovative talents, Development Knowledge should be the core of the knowledge innovation system. Only in this way can we inspire the creative enthusiasm of talents and turn the characteristics of innovation into the needs of talents [3]. It is necessary to change the concept of current innovative education ability, innovate the talent training mode of higher education institutions. The spirit of innovation should be used as the purpose of running a university to guide the construction of the university [4]. In order to achieve innovative talent training, the problem-based teaching should be adopted to cultivate students' interest in learning, guide students to be good at integrating the knowledge of multiple courses, and encourage students to consciously break through the shackles of predecessors [5]. Innovative talent cultivation is the need of the national progress and sustainable development of the university. The country's innovative ability, including knowledge innovation and technological innovation, is a decisive factor for a country to occupy a place in international competition and the world pattern. With and knowledge, In the era of rapid development of economy, one of the main factors of economic growth is the quality of laborers, that is, the level of innovation will directly affect the country's culture, comprehensive national strength and competitiveness. If a country lacks innovative ability, it will be difficult to 
have certain survival ability. As far as innovation is concerned, the foundation lies in people with innovation consciousness. Innovation talent training means people use certain tools to transform and create. Talent innovation in universities is the first element to innovation success.

\section{Scientific Orientation and Innovative Talent Training Mode}

At this stage, universities have some shortcomings in cultivating talents. Courses and exams only pay attention to the form of analytical thinking. In fact, teachers should apply multiple modes of thinking in teaching and practice. The skills of thinking should be adopted: problem determination, program selection, information representation, strategy formation, resource allocation, problem-solving monitoring and problem-solving evaluation. The innovative talents are gradually trained in the dialectical development of human life movement and thinking movement. The labor of innovative talents is to enter the field that humans have not yet recognized, which is obviously creative. Specifically, innovative talents refer to those who has innovative consciousness, innovative thinking, innovative ability and innovative personality. They are able to successfully complete innovative activities and have innovative achievements. Universities should divide innovative talents into knowledge-based innovative talents, technological innovation talents, management innovation talents, etc. according to the principle of knowledge division and innovative knowledge division of labor. In the teacher's view, knowledge-based talents are excellent talents. They can have certain innovations in theory, science and technology, scientific research, etc., and play a certain role in practical operation and application; while technological innovation talents, management innovation talents and institutional innovation talents belong to application-oriented talents. The purpose of training is to serve the production, service, construction and management for enterprises and countries in infrastructure, who play an active and effective role in practice. The orientation of teachers in universities is mainly to cultivate applied talents because the talent cultivation of universities is mainly to provide the necessary talents for the society and enterprises, but also to avoid the shortcomings of traditional talent cultivation and to constantly improve. The main target of training in universities is practical. Therefore, the talents cultivated by colleges and universities must have knowledge and ability of management, production, service, etc. At the same time, they must have the spirit of innovation and ability, who not only gain high scores but also possess practical ability. This is a requirement for university teachers to cultivate talents. As for the two aspects of innovation and application, the core aspect is innovation because innovation is the need of the market and society, which is the urgent task of the society. The application refers to the talents who are able to master the work in the workplace. They have skills, such as abilities and wisdom. In short, colleges and universities should mainly focus on creative quality, social adaptability, professional skills, knowledge, and moral qualities.

\section{Issues that should be Highly Valued}

Due to the influence of many factors such as tradition, system and environment, there are still some problems in the training of talents in colleges and universities. The traditional education model is to transfer knowledge to students. It only regards the transmission of knowledge as the essence of society but does not guide students to apply knowledge to practice, limiting the ability of students to create hands-on brains. This is obviously contrary to the current social needs. The cultivation of talents in traditional education is regarded as the process of knowledge transfer to students. The teaching and learning still stay at a single starting point, aiming at emulating, memorizing and mastering the most basic knowledge. In this process, students do not turn knowledge into their ability; in the formulation and measurement of teaching standards, teachers only explain teaching materials and the goal of students is to get a more satisfactory score in the exam; in the course of teaching, Heuristic teaching is rarely used in class, and the importance of developing students' innovative thinking skill is ignored. In addition, the traditional education mode is mainly based on teaching, and does not pay attention to the practical ability of students. Due to the limited experimental equipment in some universities in China, most of the experimental courses 
are watched by students in the laboratory. Due to the large number of students, when the teachers explain the purpose of the experiment, if the students are not focused, it is difficult to practice classroom learning in the experiment. It is difficult to have a deep understanding of the production process of the enterprise, and as for innovation it is even more difficult. When students are designing, teachers have certain deficiencies in the equipment investment of each student because of the differences in the theoretical knowledge of individual existence and the large number of students. It is difficult to predict the effect when guiding students to design, so it is even more difficult to cultivate the consciousness innovative of students. Thus students may end up with the course in the form of emulation and patchwork. Insufficient financial investment hinders the implementation of the talent training program, which directly lead to obstacles in the cultivation of innovative talents. Some teaching and research institutions do not have enough funds to purchase advanced experimental equipment, introduce high-level teachers or create a good atmosphere for the cultivation of innovative talents. What's more, the subject design is unreasonable and the training system is not perfect. The curriculum is more focused on the cultivation of students' professional ability, whose goal is to make students become experts in a certain field, rather than generalists. However, innovation is a process that requires interdisciplinary and different fields of knowledge. Only professional knowledge is often inconsistent with the standards of innovative talents that society needs. So innovation evaluation and incentive mechanisms are lacking. At present, colleges and universities are more likely to use test scores as the primary criterion for measuring students' excellence. Science and technology innovations have lower weights, so students focus more on test-taking, leading to strong ability in memory, imitation, etc., but the ability to innovate is not effectively developed and exercised. The students' subject status is not fully reflected, affecting students' development of personality. Students themselves have the characteristics of full energy and distinctive personality, which will directly stimulate the innovative thinking of them. However, the key to the development of innovative ideas lies in education. Under the existing education system, the cultivation of innovative talents has failed to be people-oriented and centered on individual student development. Students lack certainty in curriculum selection, etc. The autonomy, hobbies and personality development are limited, which leads to the difficulty of forming a sense of innovation, and the spirit of innovation is difficult to cultivate.

\section{Constantly Seeking Ways to Solve Problems}

The innovation of talent cultivation must be based on strict approaches. It is necessary to change the traditional concepts and attach importance to the cultivation of students' innovative ability. The teaching mode based on should be abandoned, the cultivation of innovation ability should be taken as the core instead of knowledge transmission, and the main position of students in the process of innovating talents should be emphasized. Teachers should guide students to find problems, think actively and solve problems creatively. It is suggested to keep up with the times and optimize the existing curriculum. The quality of political courses should be stressed, and the training of students' innovative spirit and innovative consciousness can be focused on in political courses. General increase education and the humanities and social science courses should be added to while setting professional courses. Thus, students' knowledge and thinking style can be broaden. Besides, courses and academic salons reflecting the frontiers of contemporary science and technology can be opened to students. New technologies, enabling students to keep abreast of technological trends and keep pace with the frontiers of the disciplines. It is urgent to reform the evaluation system and attach importance to innovation results. The evaluation of students should concentrate on the achievements of students in all aspects, especially science and technology innovation, which can be incorporated into the student evaluation system to examine the students' innovative performance, emphasize the importance of innovation, and motivate students to participate in innovation. Meanwhile, the education authorities should incorporate the students' innovative ability and innovation achievements into the evaluation criteria and give higher weight when conducting the teaching evaluation of universities and other scientific research units, paving the way for the cultivation of innovative talents in the system. 


\section{Conclusion}

In an era of rapid economic growth, competition among universities has become increasingly fierce. In order to cope with the ever-changing market environment, cultivating innovative talents with higher practical ability is in line with the requirements of the talent training model of colleges and universities. This needs to be carried out from three levels of research-practice-innovation. As higher education enters the stage of popularization, the talents cultivated by higher education institutions are difficult to adapt to the requirements of social change. The employment and talents of college students have become the bottleneck in the process of talents cultivation in various universities. Based on the perspective of talents training in colleges and universities, the combination of theory and practice should be used to explore the talents training models of colleges and universities, which has strong practical value.

\section{References}

[1] Guanghui Zhang. Modernization of University Governance System: Context, Appeal and Path[J]. Journal of Henan Normal University(Philosophy and Social Sciences), 2015, (2):171-174.

[2] Rushan Che, Hongbo Ji. Concept Analysis of Applied Innovation Talents [J]. University Education Management, 2015, (1): 81-85.

[3] Xiaorui Wei, Yangping Li, Weizhen Zhao, Yangyang Chen. Construction and Practice of School-Enterprise Joint Laboratory for Application-oriented Talents Training [J]. Laboratory Research and Exploration, 2015, (2):231-234.

[4] Xiaoni Zhou, Jiang Zhu. On the Cultivation of College Students' Innovative Ability [J]. Entrepreneur World (Theoretical Edition), 2010, (12):123-124.

[5] Qiuju Zheng, Zhanxuan Li. On How to Cultivate Innovative Talents in Colleges and Universities [J]. Science and Technology Innovation and Application, 2012, (2):235. 